\title{
Erratum to: AIC model selection and multimodel inference in behavioral ecology: some background, observations, and comparisons
}

\author{
Kenneth P. Burnham • David R. Anderson • \\ Kathryn P. Huyvaert
}

Published online: 22 October 2010

(C) Springer-Verlag 2010

\section{Erratum to: Behav Ecol Sociobiol \\ DOI 10.1007/s00265-010-1029-6}

The original version of this article unfortunately contained a mistake.

On page 4 , the equation used to calculate model probabilities as a strength of evidence is incorrect.

The corrected equation is given below.

$w_{i}=\operatorname{Prob}\left\{\operatorname{model} g_{i} \mid\right.$ data $\}=\ell_{i} / \sum_{j=1}^{R} \ell_{j}$.

The online version of the original article can be found under http://dx. doi.org/10.1007/s00265-010-1029-6.

K. P. Burnham $(\varangle) \cdot$ D. R. Anderson

Colorado Cooperative Fish and Wildlife Research Unit, Colorado

State University,

Fort Collins, CO 80523, USA

e-mail: kenb@lamar.colostate.edu

\section{K. P. Huyvaert}

Department of Fish, Wildlife, and Conservation Biology,

Colorado State University,

Fort Collins, CO 80523, USA
On page 6 , the presentation of table 3 was incorrect. The corrected table is given below.

Table 3 A model set for the example examining ecological factors and extra-pair paternity in a hypothetical bird species

\begin{tabular}{ll}
\hline Model description & Model notation \\
\hline Male body size ('body') & $\beta_{0}+\beta_{2 \mathrm{i}} \mathrm{X}_{2 \mathrm{i}}$ \\
Food availability ('food') & $\beta_{0}+\beta_{4} \mathrm{X}_{4}$ \\
Male dominance ('status') & $\beta_{0}+\beta_{5} \mathrm{X}_{5}$ \\
Territory quality ('territory') & $\beta_{0}+\beta_{7} \mathrm{X}_{7}$ \\
Body+food & $\beta_{0}+\beta_{2 \mathrm{i}} \mathrm{X}_{2 \mathrm{i}}+\beta_{4} \mathrm{X}_{4}$ \\
Body+status & $\beta_{0}+\beta_{2 \mathrm{i}} \mathrm{X}_{2 \mathrm{i}}+\beta_{5} \mathrm{X}_{5}$ \\
Body+territory & $\beta_{0}+\beta_{2 \mathrm{i}} \mathrm{X}_{2 \mathrm{i}}+\beta_{7} \mathrm{X}_{7}$ \\
Food+status & $\beta_{0}+\beta_{4} \mathrm{X}_{4}+\beta_{5} \mathrm{X}_{5}$ \\
Food+territory & $\beta_{0}+\beta_{4} \mathrm{X}_{4}+\beta_{7} \mathrm{X}_{7}$ \\
Body+food+status & $\beta_{0}+\beta_{2 \mathrm{i}} \mathrm{X}_{2 \mathrm{i}}+\beta_{4} \mathrm{X}_{4}+\beta_{5} \mathrm{X}_{5}$ \\
Body+food+territory & $\beta_{0}+\beta_{2 \mathrm{i}} \mathrm{X}_{2 \mathrm{i}}+\beta_{4} \mathrm{X}_{4}+\beta_{7} \mathrm{X}_{7}$ \\
Body×status & $\beta_{0}+\beta_{2 \mathrm{i}} \mathrm{X}_{2 \mathrm{i}}+\beta_{5} \mathrm{X}_{5}+\beta_{2 \mathrm{i}, 5}\left(\mathrm{X}_{2 \mathrm{i}} * \mathrm{X}_{5}\right)$ \\
Body×territory & $\beta_{0}+\beta_{2 \mathrm{i}} \mathrm{X}_{2 \mathrm{i}}+\beta_{7} \mathrm{X}_{7}+\beta_{2 \mathrm{i}, 7}\left(\mathrm{X}_{2 \mathrm{i}}{ }^{*} \mathrm{X}_{7}\right)$ \\
Food×territory & $\beta_{0}+\beta_{4} \mathrm{X}_{4}+\beta_{7} \mathrm{X}_{7}+\beta_{4,7}\left(\mathrm{X}_{4} * \mathrm{X}_{7}\right)$ \\
Intercept only & $\beta_{0}$ \\
\hline
\end{tabular}

The models link the hypothesized predictor variables from Table 2 with the probability of having an extra-pair young in the nest. Each model is a representation of the biological hypothesis of interest. Models are of the form, logit $[\operatorname{Prob}(\mathrm{EPY})]=\beta_{0}+\beta_{\mathrm{z}} X_{\mathrm{z}}$, but the notation is truncated here to list the intercept and response variables and their relationship to each other, if applicable 